\title{
Acute Hepatitis in Pregnancy: A Case Report
}

Sarmento AMP ${ }^{1}$, Oliveira ACT ${ }^{1}$, Barbosa APXP ${ }^{1}$, Campos CS ${ }^{1}$, Porto JAS ${ }^{1}$, Esteves $\mathrm{LF}^{1}$, de Morais $\mathrm{LC}^{1}$, Vilano $\mathrm{LS}^{1}$, Cerqueira MSM${ }^{1}$, Martins MC ${ }^{1}$, Cerceau $\mathrm{PS}^{1}$, Amaral $\mathrm{PHS}^{1}$, Ferreira RRMS ${ }^{1}$, Pires $\mathrm{RA}^{1}$, Albuquerque RDV ${ }^{1}$, de Souza $\mathrm{SGTPG}^{1}$, Bertges $\mathrm{ER}^{5}$, Panconi $\mathrm{CR}^{2,3,4}$, Almeida $\mathrm{FAMB}^{1}$, Zimmermmann $\mathrm{JB}^{1,2,3,4^{*}}$

${ }^{1}$ Barbacena Medical School, Barbacena, Minas Gerais State, Brazil

${ }^{2}$ Medical School of Federal University of Juiz de Fora, Juiz de Fora, Minas Gerais State, Brazil

${ }^{3}$ Zimmermmann Obstetrics and Gynecology Clinic, Brazil

${ }^{4}$ High Risk Prenatal Care, Brazil

${ }^{5} J u i z$ de Fora Medical and Health Sciences School, SUPREMA, Gastroenterology, Brazil

Corresponding Author: Juliana Barroso Zimmermmann ORCID ID

Address: Gynecology and Obstetrics Service, Barbacena School of Medicine (FUNJOBE), Barbacena, Minas Gerais State, Brazil.

Received date: 02 October 2020; Accepted date: 30 October 2020; Published date: 07 November 2020

Citation: Sarmento AMP, Oliveira ACT, Barbosa APXP, Campos CS, Porto JAS, Esteves LF, de Morais LC, Vilano LS, Cerqueira MSM, Martins MC, Cerceau PS, Amaral PHS, Ferreira RRMS, Pires RA, Albuquerque RDV, de Souza SGTPG, Bertges ER, Panconi CR, Almeida FAMB, Zimmermmann JB. Acute Hepatitis in Pregnancy: A Case Report. Asp Biomed Clin Case Rep. 2020 Nov 07;3(3):225-33.

Copyright (C) 2020 Sarmento AMP, Oliveira ACT, Barbosa APXP, Campos CS, Porto JAS, Esteves LF, de Morais LC, Vilano LS, Cerqueira MSM, Martins MC, Cerceau PS, Amaral PHS, Ferreira RRMS, Pires RA, Albuquerque RDV, de Souza SGTPG, Bertges ER, Panconi CR, Almeida FAMB, Zimmermmann JB. This is an open-access article distributed under the Creative Commons Attribution License, which permits unrestricted use, distribution, and reproduction in any medium provided the original work is properly cited.

\section{Abstract}

Introduction: Several changes occur in women's body during pregnancy, as well as several pathologies can arise at this period, such as hepatitis. It is very important to have the correct diagnosis and proper treatment for pregnant women because liver diseases can increase maternal and/or fetal morbidity and mortality rates.

Case Report: Patient in the age group 32 years, G2PoA1, thrombophilic, using ASA, enoxaparin, folate, and Bcomplex, reported jaundice, low fever, and pruritus in the $32^{\text {nd }}$ week of pregnancy. Laboratory exams showed high levels of direct hyperbilirubinemia and aminotransferases, with negative serology results for the most common viruses and autoimmunity markers. Hypervitaminosis B12 was an additional finding; it was canceled. The patient had a satisfactory recovery after support treatment.

Discussion: Hepatitis has several etiologies; it is caused by infections, medications, or triggered by the immune system. The main infectious agents causing hepatitis A, B, C, and E; Dengue, Zika, HTLV, cytomegalovirus, toxoplasmosis, rubella, and brucellosis were screened in the reported case - the patient was negative for all of them. Other possible diagnoses, such as acute liver steatosis of pregnancy, portal thrombosis, and autoimmune hepatitis were excluded. Hepatitis caused by medicines was not confirmed because clinical and laboratory exams showed improvement in the patient's clinical condition even with ASA and enoxaparin administration. The patient had high vitamin B12 level, which can be a liver damage marker. Transaminases and bilirubin showed a progressive decrease after the treatment; both patient and newborn had a satisfactory recovery. The reported condition was caused by a combination of factors, such as pregnancy hormone levels, unidentified infection, and possible predisposition to develop the disease. The patient remains under hematological and hepatological follow up, but there is no record of relapse, so far. 
Citation: Sarmento AMP, Oliveira ACT, Barbosa APXP, Campos CS, Porto JAS, Esteves LF, de Morais LC, Vilano LS, Cerqueira MSM, Martins MC, Cerceau PS, Amaral PHS, Ferreira RRMS, Pires RA, Albuquerque RDV, de Souza SGTPG, Bertges ER, Panconi CR, Almeida FAMB, Zimmermmann JB. Acute Hepatitis in Pregnancy: A Case Report. Asp Biomed Clin Case Rep. 2020 Nov 07;3(3):225-33.

Case Report

\section{Keywords}

Acute hepatitis; Autoimmunity; Hepatitis; Pregnancy; Vitamin

\section{Introduction}

Several changes occur in women's body during pregnancy as a way to ensure the availability of nutrients necessary for a healthy and sustained pregnancy. Several pathologies can arise at this period, including liver disorders exclusive to pregnancy or preexisting ones, which can get worse during this time. It is very important to have the correct diagnosis and proper treatment for pregnant women because liver diseases can increase maternal and/or fetal morbidity and mortality rates [1].

Hepatitis in pregnant women depends on several factors; it can manifest in the acute or chronic form and lead to liver damage, failure, or liver cancer [2]. Intrahepatic cholestasis of pregnancy is the most common specific liver disease observed and the second leading cause of jaundice during pregnancy, with an estimated incidence rate of approximately $1 / 10,000$ deliveries [3]. Pruritus, which can occur in up to $80 \%$ of cases, is its main symptom; other symptoms are jaundice, anorexia, general malaise, abdominal discomfort, choluria, and fecal acholia. Acute hepatic steatosis occurs in approximately 1/13,000 pregnant women, it is a potentially fatal pathology associated with $18 \%$ of maternal mortality and with $23 \%$ of fetal mortality $[1,4]$. Symptoms are unspecific and account for diagnosis delay. Nausea and vomit occur in $70 \%$ of cases, pain in the epigastrium, or right hypochondrium in 50\%-80\% of cases; flu-like symptoms are observed in some cases. Hellp Syndrome is a severe complication caused by preeclampsia; it is featured by hemolysis, elevated liver enzymes, and thrombocytopenia [1].

Viral hepatitis is one of the most common and potentially severe infections in pregnant women. It is the most common cause of jaundice during pregnancy and presents systemic manifestations. Acute hepatitis can affect pregnancy and, depending on the infectious agent, it significantly increases maternal and fetal mortality rates. Hepatitis A, B, C, D, or E viruses are the main etiological agents of hepatitis; however, even simple herpes can cause severe hepatitis. The initial symptoms often meet those of infectious conditions such as malaise, fatigue, anorexia, nausea, and pain in the epigastrium or in the right hypochondrium. Hepatomegaly and jaundice are typical of disease evolution; it is important highlighting that virus type determines the likelihood of having a chronic disease. Pregnant women with viral hepatitis need to follow-up to control encephalopathies, coagulopathies, progressive weakness, and fulminant hepatitis (which are closely related to infection caused by the E virus) [5]. Accordingly, one can observe cases of autoimmune hepatitis, which is featured by chronic hepatocellular inflammation caused by the action of circulating autoantibodies that mainly affect women at childbearing age. Pregnancy brings along an immunosuppression state that can control clinical manifestations. However, it is possible having severe malaise, anorexia, fatigue, weight loss, and acute liver failure crises with jaundice, ascites, and coagulopathies [6-8]. Drug-induced hepatitis can also happen during pregnancy and lead to adverse effects. It is a severe inflammation caused by prolonged medication use, which results in acute hepatitis or fulminant hepatitis (in most cases, asymptomatic). Two mechanisms can generate drug-induced hepatitis: toxicity or idiosyncrasy. Toxicity derives from the intake of a substance that damages liver cells and causes hepatitis, at greater or lesser severity, depending on the ingested dose. In the case of idiosyncrasy, intrinsic factors cause liver injuries and affect individuals' susceptibility; however, it does not depend on the amount of medication taken. Clinical symptoms include nausea, vomit, malaise, acute liver failure, or fulminant liver failure (in severe cases) [9-11]. Table-1 shows the main causes of hepatitis.

Authors of the current research herein report the case of a patient who developed severe hepatitis during pregnancy, her evolution, and support treatment.

\section{Case Report}

Patient, aged 32 years, G2PoA1, thrombophilic (acquired thrombophilia - antiphospholipid syndrome + MTHFR + protein S deficit) and history of fetal 
Citation: Sarmento AMP, Oliveira ACT, Barbosa APXP, Campos CS, Porto JAS, Esteves LF, de Morais LC, Vilano LS, Cerqueira MSM, Martins MC, Cerceau PS, Amaral PHS, Ferreira RRMS, Pires RA, Albuquerque RDV, de Souza SGTPG, Bertges ER, Panconi CR, Almeida FAMB, Zimmermmann JB. Acute Hepatitis in Pregnancy: A Case Report. Asp Biomed Clin Case Rep. 2020 Nov 07;3(3):225-33.

\begin{tabular}{|c|c|c|c|}
\hline \multicolumn{4}{|c|}{ Table-1: Prenatal Exams } \\
\hline \multirow{2}{*}{ Laboratory exam } & \multicolumn{3}{|c|}{ Quarter } \\
\hline & First & Second & Third \\
\hline Hemoglobin (g/dl) & 13.6 & 11.2 & 11.8 \\
\hline Hematocrit 9\%) & $33 \cdot 3$ & 33.1 & 35.1 \\
\hline Normal Lymphocytes (\%) & 31.1 & 32.2 & 31 \\
\hline Platelets (x1000) & 165 & 145 & 205 \\
\hline Glucose & 93 & 63 & 91 \\
\hline Dextrosol $75 \mathrm{~g}$ & Gestational Diabetes & & \\
\hline Syphilis & $\mathrm{N}$ & $\mathrm{N}$ & $\mathrm{N}$ \\
\hline Hepatitis C & $\mathrm{N}$ & $\mathrm{N}$ & $\mathrm{N}$ \\
\hline HIV & $\mathrm{N}$ & $\mathrm{N}$ & $\mathrm{N}$ \\
\hline Urinalysis & $\mathrm{N}$ & $\mathrm{N}$ & $\mathrm{N}$ \\
\hline Vitamin D & 32.3 & 37.7 & $39 \cdot 4$ \\
\hline Vitamin B & 454 & - & 2000 \\
\hline Ferritin & 41.6 & $35 \cdot 7$ & 38.1 \\
\hline Free Thyroxin & 0.87 & 0.94 & 1 \\
\hline Thyreotrophic Hormone & 2.2 & 2.3 & 1.5 \\
\hline Toxoplasmosis & Immune & & \\
\hline Rubella & Immune & & \\
\hline Hepatitis B & Immune & & \\
\hline Cytomegalovirus & Immune & & \\
\hline \multicolumn{4}{|l|}{ Ultrasound exam } \\
\hline First Quarter & \multicolumn{3}{|c|}{ Gestational age: 11 weeks, nuchal translucency $=0.9 \mathrm{~mm}$} \\
\hline Second Quarter & \multicolumn{3}{|c|}{$\begin{array}{l}\text { Gestational age: } 23 \text { weeks, normal fetal morphology, normal uterine } \\
\text { doppler (pulsatility index); fetal weight: } 566 \mathrm{~g}\end{array}$} \\
\hline \multirow{2}{*}{ Third Quarter } & \multicolumn{3}{|c|}{$\begin{array}{l}\text { Gestational age: } 32 \text { weeks, normal uterine doppler (pulsatility index), } \\
\text { normal umbilical Doppler, fetal weight: } 1873 \mathrm{~g} \text {, normal amniotic fluid, } \\
\text { placentae grade } \mathrm{o}\end{array}$} \\
\hline & \multicolumn{3}{|c|}{$\begin{array}{l}\text { Gestational age: } 36 \text { weeks, fetal weight: } 2879 \text {, normal amniotic fluid, } \\
\text { placentae grade and normal umbilical Doppler }\end{array}$} \\
\hline
\end{tabular}

death, taking ASA (100 mg on a daily basis), enoxaparin (40 mg on a daily basis), folic acid and Bcomplex replacement, under follow-up with hematologist and obstetrician.

She started prenatal care at the $12^{\text {th }}$ week of pregnancy and had satisfactory evolution up to the $31^{\text {st }} / 32^{\text {nd }}$ weeks when she reported to prenatal care appointment with malaise, fatigue, low fever (for one week), jaundice, and mild pruritus throughout the body. Fig-1 shows the patient clinical evolution during prenatal care based on gestational age. Table-1 shows usual prenatal laboratory and ultrasound examination results and Table-2 presents the laboratory and image 
Citation: Sarmento AMP, Oliveira ACT, Barbosa APXP, Campos CS, Porto JAS, Esteves LF, de Morais LC, Vilano LS, Cerqueira MSM, Martins MC, Cerceau PS, Amaral PHS, Ferreira RRMS, Pires RA, Albuquerque RDV, de Souza SGTPG, Bertges ER, Panconi CR, Almeida FAMB, Zimmermmann JB. Acute Hepatitis in Pregnancy: A Case Report. Asp Biomed Clin Case Rep. 2020 Nov 07;3(3):225-33.

\section{Case Report}

exams performed during jaundice. Fig-1, Fig-2 and bilirubin, respectively.

Fig-3 depict clinical evolution, transaminases, and

\begin{tabular}{|c|c|c|}
\hline \multicolumn{3}{|c|}{ Table-2: Patient's laboratory and image exam } \\
\hline \multirow{16}{*}{ Infections } & Hepatitis A & Immune \\
\hline & Hepatitis B & Immune \\
\hline & Hepatitis C & Negative \\
\hline & Hepatitis E & Negative \\
\hline & Parvovirus & Immune \\
\hline & Zika virus & Negative \\
\hline & Dengue virus & Negative \\
\hline & HTLV virus & Negative \\
\hline & Measles & Negative \\
\hline & Toxoplasmosis & Immune \\
\hline & Rubella & Immune \\
\hline & Cytomegalovirus & Immune \\
\hline & HIV & Negative \\
\hline & Syphilis & Negative \\
\hline & Urine & Negative \\
\hline & Brucellosis & Negative \\
\hline \multirow{6}{*}{ Autoimmunity } & ALKM antibody & Negative \\
\hline & Antimitochondrial antibody & Negative \\
\hline & Immunoglobulin IgG & Negative \\
\hline & Anti-TPO antibody & Negative \\
\hline & Complement $\mathrm{C}_{3}$ & 0.98 \\
\hline & Complement $\mathrm{C}_{4}$ & 0.28 \\
\hline \multirow{11}{*}{ Others } & Seric alpha- 1 antitrypsin & 325 \\
\hline & Ceruloplasmin & 70 \\
\hline & Zinc & 81.3 \\
\hline & Vitamin C & 0.54 \\
\hline & Vitamin B12 & 2000 \\
\hline & Copper & 96.8 \\
\hline & Creatinine & 0.74 \\
\hline & Folic Acid & 24 \\
\hline & Alkaline phosphatases & 50 \\
\hline & Amylase & 38 \\
\hline & Lipases & 164 \\
\hline Abdominal ultrasound & \multicolumn{2}{|l|}{ No signs of steatosis } \\
\hline
\end{tabular}


Citation: Sarmento AMP, Oliveira ACT, Barbosa APXP, Campos CS, Porto JAS, Esteves LF, de Morais LC, Vilano LS, Cerqueira MSM, Martins MC, Cerceau PS, Amaral PHS, Ferreira RRMS, Pires RA, Albuquerque RDV, de Souza SGTPG, Bertges ER, Panconi CR, Almeida FAMB, Zimmermmann JB. Acute Hepatitis in Pregnancy: A Case Report. Asp Biomed Clin Case Rep. 2020 Nov 07;3(3):225-33.

\begin{tabular}{|l|l|}
\hline \multirow{4}{*}{ Doppler ultrasound of portal system } & Hepatic artery unobstructed, with normal blood flow. IR $=0.73$ \\
\cline { 2 - 2 } & Hepatic veins with three-phase flow pattern \\
\cline { 2 - 2 } & $\begin{array}{l}\text { Superior mesenteric vein with normal caliber and hepatopetal flow of } \\
21 \mathrm{~cm} / \mathrm{s}\end{array}$ \\
\cline { 2 - 2 } & Absence of collateral circulation or unobstructed \\
\hline
\end{tabular}
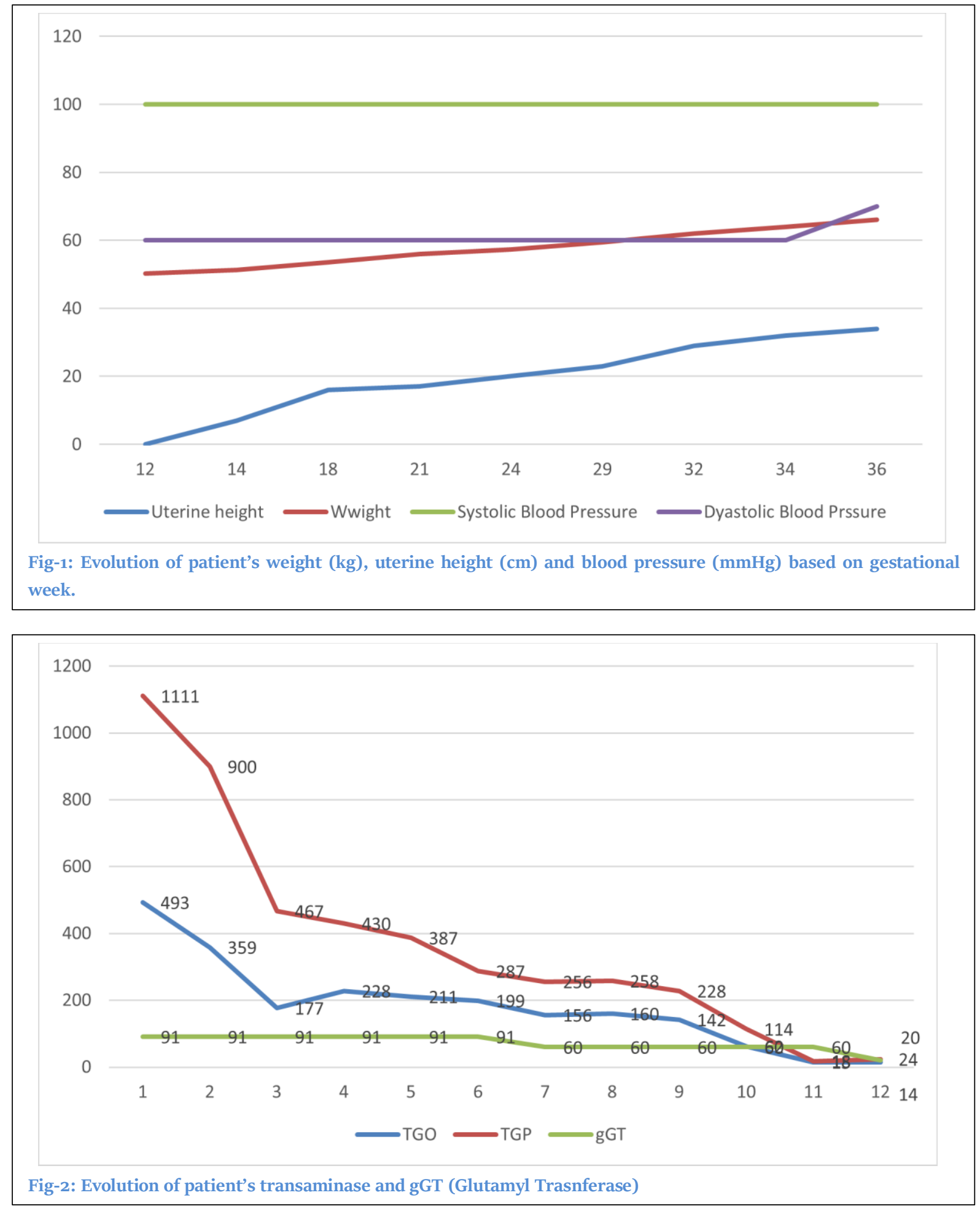
Citation: Sarmento AMP, Oliveira ACT, Barbosa APXP, Campos CS, Porto JAS, Esteves LF, de Morais LC, Vilano LS, Cerqueira MSM, Martins MC, Cerceau PS, Amaral PHS, Ferreira RRMS, Pires RA, Albuquerque RDV, de Souza SGTPG, Bertges ER, Panconi CR, Almeida FAMB, Zimmermmann JB. Acute Hepatitis in Pregnancy: A Case Report. Asp Biomed Clin Case Rep. 2020 Nov 07;3(3):225-33.

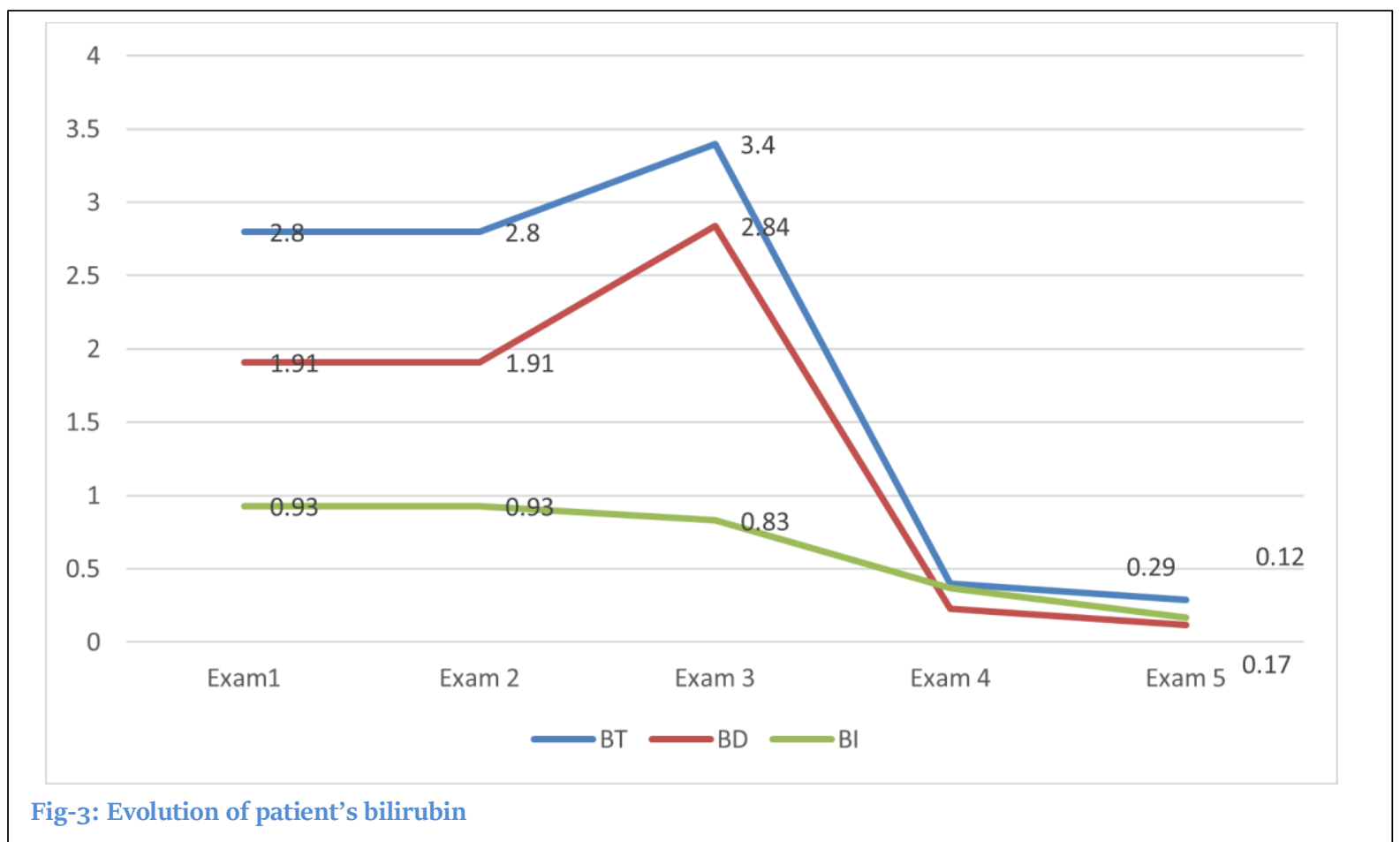

The patient continued to take enoxaparin, ASA (100 mg on daily basis), and multivitamin complex during hospitalization, except for vitamin B12, due to high rates of it reported in laboratory exams (2.00opg/mL). She had satisfactory evolution after the application of the support measures was discharged, and remains under follow-up with a hematologist and obstetrician. Pregnancy had satisfactory evolution and contractions started at the $36^{\text {th }} / 37^{\text {th }}$ weeks of pregnancy. The patient was subjected to the Cesarean section by obstetric recommendation. The newborn was in good condition and stayed in joint accommodation. They were discharged after $48 \mathrm{~h}$ of hospitalization and are well. She did not present relapse, so far. Subcutaneous progesterone was the chosen contraceptive method; all exams are stable.

\section{Discussion}

Hepatitis is a multifactor disease, caused by autoimmunity, toxicity due to medication intake, or by infections caused by bacteria, protozoa, or viruses. However, the viral infection is the most common cause of it. Hepatotropic viruses and those that cause systemic infections, such as yellow fever, Dengue, Zika, $\mathrm{CMV}$, can lead to hepatic conditions diagnosed through serology [10]. The patient was subjected to hepatitis A, $\mathrm{B}, \mathrm{C}$, and $\mathrm{E}$ examination, but her clinical condition was not related to such viruses. Hepatitis D was not screened because the patient was immune to the hepatitis B virus; she reported positive for anti-HB. Hepatitis D depends on the hepatitis B virus; it

\begin{tabular}{|c|c|}
\hline \multicolumn{2}{|c|}{ Table-3: Hepatitis etiologies } \\
\hline \multirow{8}{*}{ Virus } & Hepatitis A virus \\
\hline & Hepatitis B virus \\
\hline & Hepatitis C virus \\
\hline & Hepatitis D virus \\
\hline & Hepatitis E virus \\
\hline & Cytomegalovirus \\
\hline & Epstein Barr virus \\
\hline & Others \\
\hline \multirow{3}{*}{ Autoimmunity } & Autoimmune hepatitis \\
\hline & Primary Biliary Cirrhosis \\
\hline & $\begin{array}{l}\text { Primary Sclerosing } \\
\text { Cholangitis }\end{array}$ \\
\hline \multirow{4}{*}{$\begin{array}{c}\text { Metabolic } \\
\text { Disturbance }\end{array}$} & $\begin{array}{l}\text { Non-alcoholic Fatty Liver } \\
\text { Disease }\end{array}$ \\
\hline & Hemochromatosis \\
\hline & $\begin{array}{l}\text { Alpha-1-antitrypsin } \\
\text { Deficiency }\end{array}$ \\
\hline & Wilson's Disease \\
\hline \multirow{2}{*}{ Toxic Substances } & Alcoholic Hepatitis \\
\hline & Drug-induced Liver Disease \\
\hline
\end{tabular}


Citation: Sarmento AMP, Oliveira ACT, Barbosa APXP, Campos CS, Porto JAS, Esteves LF, de Morais LC, Vilano LS, Cerqueira MSM, Martins MC, Cerceau PS, Amaral PHS, Ferreira RRMS, Pires RA, Albuquerque RDV, de Souza SGTPG, Bertges ER, Panconi CR, Almeida FAMB, Zimmermmann JB. Acute Hepatitis in Pregnancy: A Case Report. Asp Biomed Clin Case Rep. 2020 Nov 07;3(3):225-33.

Case Report

happens in association with virus $\mathrm{B}$ or with virus $\mathrm{B}$ carriers [12]. The patient was subjected to examinations to screen other viruses, such as Dengue, Zika, CMV, and HTLV); she was negative for all of them and immune to CMV, as well as to toxoplasmosis and rubella, based on exams conducted during prenatal care - results were also negative for brucellosis. We did not identify the possible agent among the most common infectious causes of hepatitis (Table-3).

Abdominal ultrasound was performed to assess liver steatosis during pregnancy since this condition can have symptoms similar to flu, as observed in the herein assessed patient. However, abdominal ultrasound and dopplerfluxometric analysis of the portal system was regular and discarded the possibility of liver steatosis [13].

The patient was subjected to autoimmune hepatitis examination because this hepatitis type is a chronic necroinflammatory liver disease whose triggering agents are not known. It is probably the result of the interaction between genetic predisposition and external triggering agents (infections, drugs, or toxins). Antinuclear (ANA), smooth muscle (SMA), type 1 anti-liver-kidney microsomal (ALKM-1), and antimitochondrial (AMA) are the anti-bodies often screened in clinical practice; the patient was negative for all of them. Besides, the patients' clinical condition did not meet autoimmunity symptoms, which often evolve slowly (weeks to months) from lethargy and asthenia; laboratory changes and physical examination findings can suggest chronic liver disease or even cirrhosis $[6,7]$. The patient did not have any other autoimmune diseases, so this hypothesis was discarded.

Intrahepatic cholestasis of pregnancy, which has pruritus as its main symptom, mainly on palms of the hands and on foot soles, was another possibility. This pathology leads to increased concentration of bile acids in the blood, increased liver transaminases (which can reach values higher than 1,ooo U/L); however, jaundice affects less than $25 \%$ of cases and always appears after pruritus. The main element in the herein reported clinical case was jaundice, rather than pruritus, which made it possible considering other diagnostic hypotheses [10]. It is also important highlighting that intrahepatic cholestasis of pregnancy regresses two to three weeks after delivery, but did not occur in this case report [14-16]. Transaminases and bilirubin decreased during hospitalization when supportive treatment and vitamin B12 replacement was canceled.

The patient took the following medicines: multivitamin complex, intramuscular injectable vitamin B12, sodium enoxaparin (40mg on a daily basis), folate, and ASA (10omg on a daily basis). The possibility of toxicity caused by medicine taking was assessed because of enoxaparin and ASA; however, doses were only prophylactic. According to the Brazilian Society of Hepatology, ASA is a safe drug for adults and children; it is rarely associated with hepatotoxicity, except for cases of supra-therapeutic doses, which did not happen [11]. Therefore, hepatotoxicity is dose- - levels higher than $25 \mathrm{mg} / 100$ $\mathrm{mL}$ - and time-dependent. Resolution was quick after drug withdrawal; it can be reintroduced at low doses, if necessary. Salicylates can lead to hepatotoxicity; therefore, there is no advantage in replacing one aspirin for another. Histopathological findings showed non-specific focal hepatitis with hepatocellular degeneration [11]. However, there was a bilirubin rate decrease and transaminases recovery, even with medication maintenance; this outcome shows that ASA was not the cause of her liver condition. Enoxaparin can cause asymptomatic hepatic enzymes to increase up to three times the reference value [12]. However, the patient kept on taking the medicine during pregnancy because of her clinical condition; there were transaminase and bilirubin reduction. Therefore, the only medication canceled was vitamin B12, due to its high circulation level. Vitamin B12, both in parenteral and oral forms, is not associated with high transaminase activity and with apparent clinically acute liver damage; it is an unlikely etiology of hepatocyte disease [17].

Hepatic lesions can cause liver transaminases (AST and ALP) to increase, malaise, and jaundice, as observed in the assessed patient. Besides, she reported high serum vitamin B12 level assumingly associated 
Citation: Sarmento AMP, Oliveira ACT, Barbosa APXP, Campos CS, Porto JAS, Esteves LF, de Morais LC, Vilano LS, Cerqueira MSM, Martins MC, Cerceau PS, Amaral PHS, Ferreira RRMS, Pires RA, Albuquerque RDV, de Souza SGTPG, Bertges ER, Panconi CR, Almeida FAMB, Zimmermmann JB. Acute Hepatitis in Pregnancy: A Case Report. Asp Biomed Clin Case Rep. 2020 Nov 07;3(3):225-33.

Case Report

with liver damage, rather than with the prescribed replacement, since the liver is the main reservoir of this vitamin in the body and accounts for its metabolism [18]. The cause of her hepatitis was nonspecific; it was an unusual infection, since fever was recorded before its clinical manifestation, this outcome can be associated with the likelihood of natural predisposition to develop the disease. The functional deficit of vitamin B12 can have clinical consequences similar to those caused by vitamin deficit because of changes in its transport and delivery to cells [18-21]. The patient is under hematological and hepatological follow-up and showed no relapse, so far.

\section{Conflict of Interest}

All authors have read and approved the final version of the manuscript. The authors have no conflicts of interest to declare.

\section{References}

[1] Félix J. Liver Diseases in Pregnancy [Doenças hepáticas na grávida]. Intern of Gastroenterology Hospital Fernando Fonseca; 2003. Available from: https://core.ac.uk/download/pdf/62714831.pdf

[2] de Oliveira AV, Rocha FT, Abreu SR. Acute liver failure and self-medication. Arq Bras Cir Dig. 2014 Nov-Dec;27(4):294-97. [PMID: 25626943]

[3] Correia Pacheco ÁJ, Passos RS, Lucas F, Alves Sales HH, Moraes Lins Alves JM. Intra-Hypothesis of Pregnancy: Case Report [Colestase Intra-Hepática Da Gravidez: Relato De Caso]. Arquivos de Saúde, Biologia e Sociedade-ASBS. 2019 Dec 13;1(1):1-10. (Portuguese)

[4] Perosa M, Genzini T, Pandullo FL, Goldstein PJ, Ferreira CC, Miranda MA, Leitão R. Acute Liver Failure of Pregnancy - Clinical Experience with Seven Cases [Insuficiência Hepática Aguda da Gravidez Experiência Clínica com Sete Casos]. Revista Brasileira de Ginecologia e Obstetrícia. 2001 Apr;23(3):159-65. (Portuguese)

[5] Piazzal MJ, Urbanetz AA, Carvalho NS, Nascimento DJ. Viral hepatitis and pregnancy [Hepatites Virais e Gestação]. Diagn Tratamento. 2010;15(1):12-18. (Portuguese)

[6] Braga AC, Vasconcelos C, Braga J. Pregnancy with autoimmune hepatitis. Gastroenterol Hepatol Bed Bench. 2016;9(3):220-24. [PMID: 27458515]

[7] Brazilian Society of Hepatology. Definition and clinical aspects: autoimmune hepatitis [Definição e aspectos clínicos: hepatite auto-imune]. Programa de Educação Médica Continuada. (Portuguese) Available from:

http://www.sbhepatologia.org.br/pdf/FASC_HEPATO 33_FINAL.pdf

[8] Nomuras RM, Kleine RT, Igai AM, Francisco RP, Zugaib M. Clinical and obstetrical management of pregnant women with autoimmune hepatitis complicated by moderate or severe thrombocytopenia. Rev Assoc Med Bras (1992). 2013 Jan-Feb;59(1):28-34. (Portuguese) [PMID: 23440139]

[9] Larson AM. Drug-induced liver injury. UpToDate; 2019 Mar [Cited 2020 May 25]. Available from:

https://www.uptodate.com/contents/drug-induced-

liver-injury

[10] Blatt CR, Becker MW, Lunardeli MJM. Drug induced liver injury: what is the clinical pharmacist role?. Rev Bras Farm Hosp Serv Saude. 2019 Mar 11;7(4).

[11] Paraná Filho R, Pessoa M, Waksman JC, Bittencourt PL, Porta G, Bessone F, Souza AF, Rosa H, Galizzi Filho J, Martins Junior EV, Ferreira PR. Reunião com expertos em hepatotoxicidade da Sociedade Brasileira de Hepatologia: analgésicos, antitérmicos, insumos vegetais, fitoterápicos, homeopáticos e AINEs. GED gastroenterol. endosc. dig. 2011:5-47.

[12] Brasil. Ministério da Saúde. Hepatite D. Available from:

https://www.saude.gov.br/saude-de-a-z/hpv/746saude-de-a-a-z/42164-hepatite-d

[13] Pinheiro RP, Brasil IRC, Bruno SKB, Esmeraldo TC, Branco MMC, Walraven RB. Fatty liver disease and acute liver disease in pregnant women: case report literature review. Medicine [Esteatose he tose hepática a pática aguda da guda da gravidez: relato de caso revisão de literatura]. Medicina (Ribeirão Preto). 2015;48(3):315-20. (Portuguese)

[14] Tran TT, Ahn J, Reau NS. ACG Clinical Guideline: Liver Disease and Pregnancy. Am J Gastroenterol. 2016 Feb;111(2):176-94. [PMID: 26832651]

[15] Souza ED, Guerzet EA, Fava JL, Musiello RB. [Intrahepatic cholestasis of pregnancy: scientific evidence for choice of treatment] Colestase intrahepática da gravidez: evidências científicas para escolha do tratamento. Femina. 2014:39-42. (Portuguese) 
Citation: Sarmento AMP, Oliveira ACT, Barbosa APXP, Campos CS, Porto JAS, Esteves LF, de Morais LC, Vilano LS, Cerqueira MSM, Martins MC, Cerceau PS, Amaral PHS, Ferreira RRMS, Pires RA, Albuquerque RDV, de Souza SGTPG, Bertges ER, Panconi CR, Almeida FAMB, Zimmermmann JB. Acute Hepatitis in Pregnancy: A Case Report. Asp Biomed Clin Case Rep. 2020 Nov 07;3(3):225-33.

Case Report

[16] Manzotti C, Casazza G, Stimac T, Nikolova D, Gluud C. Total serum bile acids or serum bile acid profile, or both, for the diagnosis of intrahepatic cholestasis of pregnancy. Cochrane Database Syst Rev. 2019 Jul 5;7(7):CDo12546. [PMID: 31283001]

[17] LiverTox: Clinical and Research Information on Drug-Induced Liver Injury [Internet]. Bethesda (MD):

National Institute of Diabetes and Digestive and Kidney Diseases; 2012-. Vitamin B. 2016 May 9. [PMID: 31644020]

[18] Kothadia JP, Shah JM. Autoimmune Hepatitis and Pregnancy. 2020 Mar 30. In: StatPearls [Internet]. Treasure Island (FL): StatPearls Publishing; 2020 Jan. [PMID: 31334990]

[19] Paniz C, Grotto D, Schmitt GC, Valentini J, Schott KL, Pomblum VJ, Garcia SC. Physiopathology of vitamin B12 deficiency and its laboratorial diagnosis [Fisiopatologia da deficiência de vitamina B12 e seu diagnóstico laboratorial]. Jornal Brasileiro de Patologia e Medicina Laboratorial. 2005 Oct;41(5):323-34. (Portuguese)

[20] Bes P. Grávidas com taxas insuficientes de vitamina B12 geram filhos com a mesma deficiência [internet]. São Paulo; 2003. [Cited 2020 May 22]. Available from:

http://www.usp.br/aun/antigo/exibir?id=568\&ed $=52$ $\& \mathrm{f}=30$

[21] Veraldi S, Benardon S, Diani M, Barbareschi M. Acneiform eruptions caused by vitamin B12: A report of five cases and review of the literature. J Cosmet Dermatol. 2018 Feb;17(1):112-15. [PMID: 28594082] 